\title{
Protecting the Biodiversity of the Arabic Gulf's Coastal Waters from Agricultural and Industrial Runoff Case Study-Saudi Arabia
}

\author{
D. Alzahrani and Huda Alqasmi
}

\begin{abstract}
The protection of environment especially marine resources has become a challenge since the 20th century. Many factors contribute this problem especially the increase demand of growing economy and industry. This article will critically examine and evaluate the Saudi Arabian efforts in protecting the marine environment especially the Arabic Gulf through analysing both national and international environmental laws in addition to the current environmental challenges in Saudi Arabia.
\end{abstract}

Index Terms-Environment, pollution, protection, Saudi Arabia, agricultural, industrial.

\section{INTRODUCTION}

The rapid growth in economics and industry puts environment conversation into question world-widely and Saudi Arabia is no exception. Given the fact that Saudi Arabia's land is mostly dessert, protecting other vulnerable resources is essential especially marine treasure. Thus, this article will examine the current status of coastal protection in Saudi Arabia with special focus on the Arabic Gulf. Firstly, the paper is going to overview the current geographical, political and legal situations in Saudi Arabia. Secondly, the relationship between the national and international environmental laws will be explored focusing on the Saudi Arabia reaction towards the international treaties. Thirdly, this paper will explore, generally, the current environmental issues in Saudi Arabia. Lastly, attention will be drawn to marine conservation particularly the Arabic Gulf. This article concludes by asserting that a special and immediate attention should be given to the protection of the Arabic Gulf's resources with several recommendations.

\section{A. Geographical Overview}

Saudi Arabia comprises most of the Arabic peninsula, a major landmass in the Middle East between Africa and Asia, bordered by Iraq, Kuwait and Jordan to the north, the Red Sea to the west, Yemen, Oman and the United Arab Emirates to the south and southeast, and the Persian Gulf to east.[1] Saudi Arabia is roughly one-fifth the size of the United States, and its population is 26.1 million, less than one-tenth the population of the United States. The terrain is primarily desert,

Manuscript received November 3, 2012; revised January 1, 2013. This work is a part of research sponsored by the King Abdullah Scholarship Program for both writers.

Damna A. Alzahrani is with the University of Western Australia, Faculty of Law, Perth, Western Australia(e-mail:damnaz@ hotmail.com).

Huda A. Alqasmi is with Graduate School of Business and Law, RMIT University (e-mail: alqasmi_h@yahoo.com). though there are mountains in the southwest. The coastal areas and waters are the most environmentally-abundant regions, with significant fisheries, plant life, corals and marine mammals [2].

\section{B. Political Introduction}

Under the Constitution of the Kingdom of Saudi Arabia, Islam is the state religion and Arabic is the official language. While the monarchy's authority remains unchallenged and supreme in the Kingdom of Saudi Arabia, recent efforts to modernize and reform the political system present the possibility for significant change [3]. These reforms have included municipal elections and greater rights and educational opportunities for women. There are no political parties in Saudi Arabia. The king also serves as Prime Minister, and he selects his own cabinet, called the Council of Ministers [4].

\section{Introduction of the Legal System and Legislative Processes}

The Council of Ministers is the primary legislative body in the Kingdom. In addition, a council within the Council of Ministers, the Consultative Council, is authorized to make legislative resolutions. However, it should be noted that either council only makes resolutions, and they are ratified by royal decree [4]. The laws are subject to judicial review by a system of religious courts that apply Shari'a law [4]. The court system is relatively independent in Saudi Arabia. Formerly, the Ministry of Justice had the authority to establish and abolish courts and name judges. However, in 2007 a new law created a new Supreme Court, which replaced the Supreme Judicial Council as the highest legal authority. Meanwhile, the Supreme Judicial Council assumed the authority formerly given to the Ministry of Justice to establish and abolish courts, and name judges.

\section{STATE OF ENVIRONMENTAL LAWS AND REGULATIONS}

\section{A. National}

As the Kingdom of Saudi Arabia aspires to become a developed country by the year 2025, which will be achieved in 18 years through a set of three 5-year strategic plans, it is important for Saudi Arabia to transform itself into an environmentally knowledgeable society which can lead to sustainability. Saudi Arabia plans to take bold steps to develop and reform its current environment regulations [1].

Domestic environmental law is guided by the "General Environmental Law and Rules for Implementation," last 
revised October 15, 2011, and overseen by the Presidency of Meteorology and Environment [2]. The law contains three sections: General Environmental Law, Rules for Implementation and Environmental Protection Standards. General Environmental Law outlines agency duties, agency environmental obligations, including regulations related to Environmental Impact Assessments, environmental education requirements, principles of sustainability and resource utilization, pollution standards, development mitigation measures, management of hazardous materials and penal issues for violations.

Rules for Implementation include specific agency duties, including environmental assessment, environmental reporting, collection of environmental information, setting licensing and regulatory standards, and project management [2]. Specific details of Environmental Impact Assessments are provided in this section. Specific details of penal actions and authority are also provided.

The Environmental Protection Standards provides for the evaluation and regulation of industrial and urban activities with an impact on the environment [2]. The need for economic development is stated as a principle that must be accommodated with environmental protection. This section notes the agency's authority to offer exemptions to existing environmental laws and regulations [1]. In addition, specific standards for pollutant emissions are provided under Environmental Protection Standards.

\section{B. Internationally}

Saudi Arabia is a party to number of international environmental conventions and treaties, including the following:

Saudi is a signatory to most of the major international frameworks related to biodiversity protection and protection of the marine environment. Saudi signed the Convention on Biological Diversity since 2001 [5]. The Convention attempts to promote biodiversity protection by encouraging scientific research, environmental assessment, public awareness, financial support, and national reporting on efforts to meet the treaty commitments. Saudi's primary interaction with the Convention has been the establishment of the National Biodiversity Unit, the expansion of environmental research, the establishment of environmental impact assessment for development projects, and improvement of human capital through participation in international conferences [1].

Saudi Arabia is a party to regional and international conventions for protection of the marine environment. Since the mid 1970s, Saudi Arabia has been concerned about marine pollution, but at present concern is greater than at any other time in the past. Saudi Arabia shares a common interest with the international community in the protection of the marine environment. The major international conventions of oil pollution to which Saudi Arabia is a party are the International Convention for the Prevention of Pollution of the Sea by Oil and its amendments of 1962, 1969 and 1971[6] OILPOL regulates vessel-source pollution by imposing limitations upon deliberate, "operational" discharges of oil or oily mixtures. Also, the 1969 International Convention on Civil Liability for Oil Pollution Damage and its Protocol of 1976 CLC [7], seeks to provide compensation to those who sustain damage from oil spills caused by accident and casualties, and to determine liability for such payments.

There have been other conventions to which Saudi Arabia has become party, such as International Convention relating to Intervention on the High Seas in Cases of Oil Pollution Casualties [8], as well as the 1971 International Convention on the Establishment of an International Fund for Compensation for Oil Pollution Damage (Fund Convention) [9].

In addition, the Kingdom is a party to the 1982 UNCLOS [10], which represented the first attempt to set out a general framework for the control and protection of the marine environment through its Part XII. The Convention addresses six main sources of sea pollution [10]. Furthermore, Article 194 specifies that anti-pollution measures must protect and preserve rare or fragile ecosystems and the habitat of depleted, threatened or endangered species and other forms of marine life [10]. The protection of trade routes for international shipping was one important element of this convention, and the rights of innocent passage in the territorial seas and transit passage in straits were primarily designed to ensure that international shipping operated efficiently [10], rather than with environmental sensitivity.

Saudi Arabia is not a party to the 1973/78 MARPOL Convention, as amended by the Protocol of 1978, although this convention and its annexes would considerably extend the scope of protection against pollution of the sea from ships other than from dumping. Annex I to the Convention is concerned with oil, Annex II with noxious liquid substances in bulk, Annex III with harmful substances carried by sea in packaged forms, Annex IV with sewage, and Annex V with garbage.

Saudi Arabia is a party to the International Convention for the Prevention of Pollution of the Sea by Oil (OILPOL) [6]. Saudi Arabia has also led regional efforts to protect the Red Sea under the Jeddah Convention of 1982 and later amendments [11]. However, Saudi Arabia has refused to ratify other international environmental conventions, such as the International Convention for the Prevention of Pollution from Ships, based primarily on the fear that such environmental agreements would hinder oil and natural gas industries [12]. Saudi Arabia's participation in international environmental agreements reflects an interest in displaying concern for the environment while limiting the reach of these agreements to inhibit economic development and current industrial activities.

\section{AdDRESSING CURRENT ENVIRONMENTAL PROBLEMS AND IMPLEMENTATION ISSUES}

The lack of transparency in Saudi Arabian society inhibits the ability to conduct a complete evaluation of environmental problems in the Kingdom. However, the Kingdom's Presidency of Meteorology \& Environment has allowed environmental scientists and academic policy analysts to publish several articles in Western peer-reviewed journals, and the agency has also conducts its own assessments and published them for international review [13]. These sources reveal several environmental problems in general. 
First, shipping in the Red Sea and the Arabic Gulf presents a significant threat to the marine environment and coastal land masses [1]. This is one of the most trafficked shipping areas of the world, responsible for transporting much of the world's fossil-fuel energy. The potential for spills and discharges is significant and believed to threaten marine mammals, corals, fisheries and sea bird populations in the open sea and in coastal and island areas. Such harm is extended to people's life as consumers and residents.

Second, residential and commercial development as the result of population growth and economic development tends to locate near environmentally sensitive areas, particularly coastal areas, mountains and unique desert habitat [14]. The desire for multifaceted economic diversification is a major priority of the Kingdom, and economic interests often override environmental concerns.

Lastly, industrial development related to exploitation of fossil-fuel resources presents major hazards to air and water quality, as well as to the destruction of habitat [14]. Since fossil fuel represents the foundation of Saudi economic activity and provides for a high quality of life for the population, industrial interests often override environmental concerns.

Saudi Arabia has made significant improvements in drafting environmental laws, raising environmental awareness in schools, and constructing an academic, scientific and regulatory system [14]. However, this effort is considered far below the systems, structures and policies for environmental protection in the developed world. There are significant structural barriers to effective implementation of environmental law as a result of political hierarchy and inequality.

\section{MARInE EnVIRONMENTAL IsSUES - CASE StUdy}

One of the key problems confronting biodiversity in the Arabic Gulf is the pollution of coastal waters from land-based industrial operations. According to the United Nations, the biodiversity of the Arabic Gulf's coastal sea-grass and coral is threatened by industrial and agricultural runoff, which contaminates the water with harmful pollutants, including toxins, carcinogens, minerals and thermal pollution [15]. Indeed, industrial and agricultural runoff that is treated still threatens biodiversity because it changes the mineral content and temperature of the coastal waters. As the countries surrounding the Arabic Gulf continue to develop economically, the biodiversity of the Arabic Gulf's coastal waters will continue to degrade.

Saudi Arabia attempts to protect the biodiversity of the Arabic Gulf with its General Environmental Regulations, which establishes Agency responsibility for enforcing environmental laws and regulations, including environmental assessment of sensitive ecological areas [2]. The General Environmental Regulations provide the basic principles for environmental protection in Saudi Arabia. Specifically, the Meteorology and Environmental Protection Administration (MEPA) [16], is required to conduct environmental assessments of the coastal waters to monitor the scope of environmental degradation and propose solutions for protection and remediation. Since the Arabic Gulf War and the massive oil spills that occurred during that conflict, MEPA has engaged in extensive environmental assessment and monitoring of the Arabic Gulf coastal waters.

Efforts undertaken by MEPA with the assistance of private contractors have included removal of oil with sorbent pads, oil mops, and vacuums. In addition, heavy contaminated algal mats were removed to prevent further contamination to ecosystem. Trenches and other infrastructure improvement to the coastal area were undertaken by prevent further industrial runoff into the Arabic Gulf coastal waters. Lastly, MEPA established a control site to monitor further degradation of the coastal waters from spill off [1].

The Arabic Gulf's marine environment is the focus of international law, specifically the Regional Organization for the Protection of the Marine Environment, which was created in 1979 by a collection of Arabic Gulf states, for the purposes of "addressing marine emergencies, hazardous wastes, land-based activities and sea-based pollution" [17]. The ROPME is also aligned with the United Nations Environment Program. However, this relationship does not cede any authority to the United Nations. Rather, ROPME functions as a "Non-UNEP Administered Program" [18]. This legal arrangement only allows for cooperation between the member states of ROPME, and the United Nations, but the greater enforcement power of international law is diminished by the ROPME's designation as a Non-UNEP Administered Program.

Obviously, this decision by ROPME to maintain control by member states and the regional body is intended to diminish the ability of international law to protect the coastal waters of the Arabic Gulf. The member states rely on industrial activity for their economic well-being, and they likely perceive international law as a threat to their national sovereignty to decide for themselves how their coastal territorial waters should be managed. There is an obvious parallel with human rights law. The United States refuses to sign international law regarding war crimes because it fears that its soldiers could be subjected to war crimes tribunals by political opponents in Europe or the Middle East. As long as national sovereignty remains foremost in the minds of national leaders, neither human-rights nor environmental law will have any relevance in restraining harmful behaviors.

Indeed, international law gives the rights of nations with oceanic borders to enforce their own laws within territorial waters. The United Nations Convention of the Law of the Sea was primarily interested in ensuring navigational trade routes and maintaining national sovereignty over territorial waters [10]. The establishment of Exclusive Economic Zones under the Convention serves to maximize industrial activities along coastal waters and give nations rather than international law the right to enforce its own laws. Ironically, international law under the Convention of the Law of the Sea ensures the continued weakness of international law to protect the environment from activities allowed and promoted by member states.

To sum up, protecting the biodiversity of sea-grasses and corals in the coastal waters of the Arabic Gulf will require member states of ROPME to increase their environmental awareness and concern, or to cede greater authority for 
environmental protection to international bodies. Neither of these scenarios is likely given the authoritarian nature of these regimes and their primary emphasis on economic development over environmental protection. The evolution of environmental awareness will have to emerge as a cultural force before it is reflected in national or international law. Moreover, the states surrounding the Arabic Gulf will need to evolve more transparent and responsive governments that honor the emergence of environmental activism. In the West, challenges to economic development are only made as a result of political and legal freedoms that allow environmental activists to challenge harmful activities. The political and legal arenas of the states of the Arabic Gulf are resistant to providing such freedoms and rights, and thus the biodiversity of the Arabic Gulf will remain threatened.

\section{CONCLUSION}

In conclusion, marine resources are highly valuable resources especially to Saudi Arabia. Having acknowledged that, Saudi Arabia should expand the efforts to protect such treasure. There are number of ways to achieve that goal. First, a balance between economic and environmental interest should be established. Of course, training and researching new ways to protect the environment, while keeping economic productivity will be one of the highly recommended actions. Protecting the environment and the economy would ensure the states' well-being which is, of course, one of the main goals of Saudi Arabia.

\section{REFERENCES}

[1] A. Damna, Legal action to protect the marina environment from oil pollution in the Red Sea: case study of Saudi Arabia, Alsark press, 2010, pp. 6.

[2] Presidency of Meteorology \& Environment Kingdom of Saudi Arabia, General Environmental Law and Rules for Implementation, 2011, pp. 23-31.

[3] Z. Mic, Saudi Arabia law, TR Press, 2004, 32.

[4] F. E. Vogel, Islamic Law and Legal System: Studies of Saudi Arabia, Brill, 2000, pp. 34-53-90.

[5] United Nations Environmental, The Convention on Biological Diversity, 1993, pp.4.
[6] United Nations Environmental, The Convention for the Prevention of the Pollution of the Sea by Oil, 1958, pp. 10.

[7] United Nations Environmental, The International Convention on Civil Liability for Oil Pollution Damage (CLC), 1975, pp. 4.

[8] United Nations Environmental, The International Convention Relating to Intervention on the High Seas in Cases of Oil Pollution Casualties, 1975, pp. 2.

[9] United Nations Environmental, The International Convention on the Establishment of an International Fund for Compensation for Oil Pollution Damage, 1978, pp. 4.

[10] United Nations Environmental, United Nations Convention on the Law of the Sea, 2010, pp. 21.

[11] United Nations Environmental, The Regional Conference on the Conservation of the Marine Environment and Coastal Areas in the Red Sea and Gulf of Aden, Jeddah Convention JC, 1985, pp. 29.

[12] United Nations Environmental, MARPOL, The amendments to prevent pollution during ship-to-ship oil transfer operations, 2011, pp.18-20.

[13] Z. Sami, "Saudis Attitudes toward Chemical Population Pollution of the Environment, "Human and Ecological Risk Assessment, pp. 16, 2010.

[14] V. Peter, Saudi Arabia: An Environmental Overview, New York: Psychology Press, 2008, pp. 23.

[15] United Nations Environment Program, The Persian Gulf Marine Environment, 2010. pp. 3.

[16] M. Al Jadaan, Saudi Arabian Environmental Laws, 2004. pp. 11.

[17] Regional Organization for the Protection of the Marine Environment ROPME Sea Areas Report, 2010, pp. 7.

[18] United Nations Environmental, Non-UNEP Administered Programs, (2010), pp. 14

Damna A. Alzahrani is currently a PhD Candidate at the University of Western Australia, Faculty of Law, Perth, WA, Australia. Thesis Topic: Heritage, Conservation and Good Governance. Damna holds a Master Degree in International Environmental Law 2011 from Macquarie University, Sydney, Australia. She holds another Master degree in History 2009 from King Abdulaziz University, Jeddah, Saudi Arabia.

She Granted a Scholarship from King Abdullah Scholarship Program through Saudi Ministry of Higher Education to study at The University of Western Australia, Faculty of Law, Perth, Western Australia.

Huda Alqasmi is a PhD Candidate at Graduate School of Business and Law, RMIT University, Melbourne, Victoia thesis topic: Consumer Protection Law and Sustainable Development in Saudi Arabia.

Huda holds a Master degree in International Trade and Commerce Law from Macqaurie University, Sydney. She Granted a Scholarship from King Abdullah Scholarship Program through Saudi Ministry of Higher Education to study at RMIT University, Graduate School of Business and Law, Melbourne, Victoria. 